\title{
A Simple System Dynamics Model for the Global Production Rate of Sand, Gravel, Crushed Rock and Stone, Market Prices and Long-Term Supply Embedded into the WORLD6 Model
}

\author{
Harald U. Sverdrup ${ }^{1,3}$ (I) Deniz Koca ${ }^{2} \cdot$ Peter Schlyter $^{3}$
}

Received: 28 November 2016 / Accepted: 12 April 2017 / Published online: 18 May 2017

(C) Springer International Publishing Switzerland 2017

\begin{abstract}
A model for global supply of sand, gravel and cut stone for construction based on a system dynamics model was developed for inclusion in the WORLD6 model. The Sand-Gravel-Stone model simulates production and market supply, demand and price for natural sand and gravel, sand and gravel from crushed rock and cut stone. The model uses market mechanisms where the demand is depending on population size, maintenance and price. For the period 2000-2050, the WORLD6 model outputs correlate with the GINFORS model outputs $\left(r^{2}=0.98\right)$, but they may take different pathways after 2050 . The resources of sand and gravel are estimated at 12 trillion ton each, another 125 trillion tons of rock is suitable for crushing to sand and gravel and at least 42 trillion ton of quality stone is available for production of cut stone. The simulation, under assumed business-as-usual conditions, shows that cut stone production will reach a maximum level by about 2020-2030 and stabilize after that. The cause for this is that demand exceeds extraction as well as slow exhaustion of the known reserves of high-quality stone. Sand and gravel show plateau behaviour and reach their maximum production rate in 2060-2070. The reason for the slight
\end{abstract}

Electronic supplementary material The online version of this article (doi:10.1007/s41247-017-0023-2) contains supplementary material, which is available to authorized users.

Harald U. Sverdrup

hus@hi.is

1 Industrial Engineering, University of Iceland, Hjardarhagi, 2-6, 107 Reykjavik, Iceland

2 Center for Environmental and Climate Research, Lund University, 22362 Lund, Sweden

3 Department of Physical Geography, Stockholm University, 10691 Stockholm, Sweden peak towards a plateau behaviour is partly driven by an expected population decline and increasing prices for sand and gravel, limiting demand. Assuming business-as-usual conditions rates remain at that level for centuries.

Keywords Sand - Gravel $\cdot$ Cut stone $\cdot$ System dynamics . Natural resources

\section{Introduction}

A conventional view is that there is, for practical purposes, endless resources of sand, gravel and stone on the earth for human use. Given that we are in the midst of the great acceleration in resource extraction and use (Steffen et al. 2015), this view needs to be critically examined. Construction materials, such as sand, gravel, stone aggregates and rock are fundamental for human development and wellbeing. Materials play a central role in the economy, and stony aggregates are one of the largest material flows humans move around in terms of weight. Sand and gravel occur naturally either as naturally sorted aggregates or as mixed aggregates. Some measure of crushing is also frequently employed. USGS (2015) and UNEP GEAS (2014) estimate that sand, gravel and stone materials use in construction amounts to about 47-59 billion tons per year, the range shows the uncertainty in the estimate. Sand and gravel, account for both the largest share (from 65 to $85 \%$ ). The world's use of aggregates for concrete can be estimated at 26-30 billion ton a year for 2012 (BMI 2014; Chilamkurthy et al. 2016; Giljum et al. 2008; 2011). Another large driver in North America for sand demand was the activity of fracking for shale gas (BMI 2014). China, India, Brazil, USA and Turkey are currently the world's biggest concrete producers, 
with China and India accounting for two-thirds of total global production. In the past 20 years, cement demand in China has increased fourfold compared to a growth of about 58\% in the rest of the world (Giljum et al. 2008, 2011; UNEP 2014). There are significant concerns about the sustainability of the present global material extraction rates, including the issue of sand, gravel and stone extraction rates (Aquaknow 2014; Bardi 2013; Giljum et al. 2000, 2008, 2011; Heinberg 2001, 2011; Horwath 2004; Krausmann et al. 2009; Meadows et al. 1972, 1974, 2005; Morrigan 2010; Nickless et al. 2014; Peduzzi 2014; Sverdrup and Ragnarsdottir 2014).

Until recently, most construction sand was mined from riverbanks and local pits. With the dramatic increase in demand, industrial scale marine and beach sand mining are increasingly common, along with sand and gravel made from industrially crushed stone (BMI Research 2014; Langer 2002, 2014; Merwede 2014; OSPAR 2003; Radzevičius et al. 2010; Robinson and Brown 2002; Velegrakis et al. 2010; Sutphin et al. 2002; Morrow 2011; Krause et al. 2010; Ravishankar 2015; Anthoni 2000; Ashraf et al. 2011).

While many of the world's deserts are rich in sand, much of the material is often too well sorted, have the wrong shape (the grains may be round and polished) or too fine grained for use in construction materials. Crushed sand and gravel are characterized by the fact that the particles are sharp edged thereby binding well with cement owing to their shape. The more polished and rounded the particles of deserts and certain beaches are, the less suitable they are for construction and, in particular, as fillers in cement. Thus, a large part of natural sand and gravel deposits found will be unsuitable for construction and building because of wrong physical properties.

Sand mining, irrespective of where it occurs, usually has major environmental impacts. Earlier modelling approaches have been attempted, however, the methods used have some significant shortcomings. Econometric input/output table generated time series work as a short-term extrapolation tool, but lacks stocks and thus cannot handle delays. Only a limited amount of feedbacks is possible in such models, and the inclusion of market dynamics mechanisms is not possible. Material flow analysis can deal with stocks, but only step forward in a spread-sheet manner. Thus, no market dynamics or systemic feedbacks can be included (Graedel and Allenby 2003; Moll et al. 2002; Nakamura et al. 2007; HirschnitzGarber et al. 2015; Sverdrup and Ragnarsdottir 2014; Pauliuk et al. 2015). In the WORLD6 model being developed by the authors, most major resources (metals, rock materials, fossil energy, renewable energy, phosphorus, agricultural land, population) are modelled together with their causal connections through energy consumption, infrastructures and mass balances. The WORLD6 model generates resource supply to global markets and generates global supply and global market prices endogenously.

\section{Objective and Scope}

The objective is to make and test a first global assessment of long-term use and availability of sand, gravel, stone and rock for human use through an integrated global model for the extraction and market supply of sand, gravel (glacial, fluvial and marine) and cut quality stone from rock for construction needs. The model will be tested on independent observed data-production and market price-to ensure that the model developed has satisfactory performance. The purpose is to make a simplified model that will still perform satisfactorily well when compared to the available data. A secondary objective is to link such a model within the WORLD6 model being developed by the authors. The test here will be module performance inside the WORLD6 model to be assessed by comparing observed data and consistency with the outputs of the GINFORS model. Finally, global production rates, prices and supply of sand, gravel, crushed rock and stone will be assessed using the model. The standard for evaluating the performance of the model will be by comparison to observed data on sand, gravel and cut stone extraction rates, rates of sand and gravel from crushing of stone and recorded market price for sand, gravel and cut stone.

It is outside the scope here to make a sensitivity analysis of the Sand-Gravel-Stone (SGS) sub-model in WORLD6 and explore its sensitivity. We will analyse the model qualitatively using the available causal loop diagrams, but the rest will be the subject of a future study. It is also outside the scope of this study to investigate different policy interpretations or future policy options. That will be the subject of a future study. The model is run for the time interval from 1900 to $2400 \mathrm{AD}$, or 500 years; 115 years of known history to evaluate the model and validate its performance and for 385 years under assumed business-as-usual conditions. We have adopted the long time-span because of the long delays in the system (residential time in use of 100 years) and that a proper run should normally cover at least three system delay times to evolve through all the inherent dynamics of the system. An approach of using business-asusual was adopted. Alternative pathways are thinkable, but this will be the subject of later studies.

\section{Methods and Theory}

\section{Reserves}

Owing to data constraints several approaches to quantification of reserves and resources have been taken. The reserve 
estimates are based on classical Geological Survey estimates, and the allocation of extractable amounts according to ore quality, stratified after extraction costs (Singer 1993, 1995, 2007; Singer and Menzie 2010; Sutphin et al. 2002; Stockwell 1999; US Environmental Protection Agency 1994; USGS 2009, 2013; US department of the interior 1980; Sverdrup et al. 2015a, b, c, d). However, an extensive compilation of regional reserve and resource assessments have not yet been done, making our reserve and resource estimates difficult to do with accuracy. For sand, gravel and stone the data availability is less straightforward in the sense that while there is a wealth of information at small local scales, but few regional summaries and compilations there is almost none at the global scale. Our resource estimates for sand, gravel and stone are very approximate, and are of a back-of-the-envelope type of approximation that may need to be revised dramatically in the near future (Singer 1993; Kostka 2011; Kogel et al. 2006).

\section{Defining Scarcity}

Before we go on, we need to define the term scarcity. We define scarcity as follows:

- Soft scarcity

- Demand is decreased because of higher prices, when demand outmatch supply;

Reduced consumption is the result

- Hard scarcity

- Economic scarcity; the price increases to high because of supply shortage and society or industry runs out of money to buy.

Less provision at higher cost is the result In severe cases,

- Risk for economic crisis

- Significant loss of opportunity

- Physical scarcity; the material is physically unavailable regardless of price

Failure of provision is the result

In severe cases, risk for economic crisis and/ or social disruptions if significant resources are affected

This implies that persistent price increases are an indicator of soft scarcity, and this may occur long before any physical scarcity is visible. Soft scarcity is frequently occurring in society, it is reflected in changes in price.
Society is well adapted to handle soft scarcity. Hard scarcity has more severe effects, and for general large-scale commodities, hard scarcity may be disruptive. Hard scarcity occurs already for some commodities, and is reflected by very high and strongly fluctuating prices. Examples where this occur are metals like, platinum, rhodium or rhenium. The results of our simulations will be evaluated with respect to this definition of scarcity.

\section{System Dynamics Modelling}

Standard methods of system analysis and system dynamics have been used (Sterman 2000; Senge 1990; Sverdrup and Svensson 2002, 2004; Haraldsson and Sverdrup 2004; Sverdrup et al. 2014a, b; 2015a, b). Material flow pathways and the causal chains and feedbacks loops in the system are mapped using a causal loop diagram (CLD) methodology. The resulting coupled differential equations are transferred to computer codes for numerical solutions using the STELLA ${ }^{\circledR}$ system dynamics software (Fig. 4). For validation, to assess performance and robustness of the model, it is used to reconstruct the past (1900-2015). When performance is satisfactory, the model is used to simulate the future (2015-2300) under business-as-usual (BAU) conditions. In this context, it is important to stress that we do not aim to prognosticate or describe the likely future at this future timescale but rather to illustrate implications on resource use and availability under assumed BAU conditions. The iterations were used to set the parameterization to such values that the mining history, observed ore grades and price picture could be reproduced. This allows us to see where the intervention points in the system are, and to propose policy interventions (Haraldsson and Sverdrup 2004; Bardi and Lavachi 2009; Sverdrup and Ragnarsdottir 2014).

\section{Earlier Use of Global System Dynamics Models}

We have earlier successfully employed these methods and quantification approaches for assessments of Rare Earths (Kifle et al. 2012), natural resources in general (Sverdrup et al. 2012b, 2013, 2017b); copper (Sverdrup et al. 2014a); silver (Sverdrup et al. 2014b), aluminium (Sverdrup et al. 2015a), Gold (Sverdrup et al. 2012a), platinum (Sverdrup et al. 2017a); lithium (Sverdrup 2016) and further papers being prepared for iron (Sverdrup et al. 2015b), stainless steel, nickel, manganese, chromium (Sverdrup 2016), copper, lead, zinc, indium (Sverdrup et al. 2015c; Sverdrup and Ragnarsdottir 2016), molybdenum and rhenium (Sverdrup 2016) and cobalt (Sverdrup et al. 2015c). There are other simpler modelling methods available, but we have avoided these as they lack market dynamics and they lack most of the feedbacks known to be present in the real global mining 
and metal trading systems (Bardi and Lavacchi 2009). The model also profited from the earlier efforts by Meadows et al. (1974) in preparation of the "Limits to growth" study (Meadows et al. 1972). The SGS model was initially developed as a stand-alone model, driven by several exogenous variables. Then it was incorporated into the WORLD6 model, and operated from within that structure.

\section{Model Description}

Figure 1 shows a basic flow chart for the SGS model. The SGS model has the following stocks used to define the coupled differential equations from mass balance (Fig. 1):
1. Sand

(a) Mineable stocks

(i) Known sand

(ii) Hidden sand

(b) In society, we distinguish two above-ground stocks

(i) Sand in trade market

(ii) Sand stock-in-use in society

2. Gravel

(a) Mineable stocks

(i) Known gravel

(ii) Hidden gravel

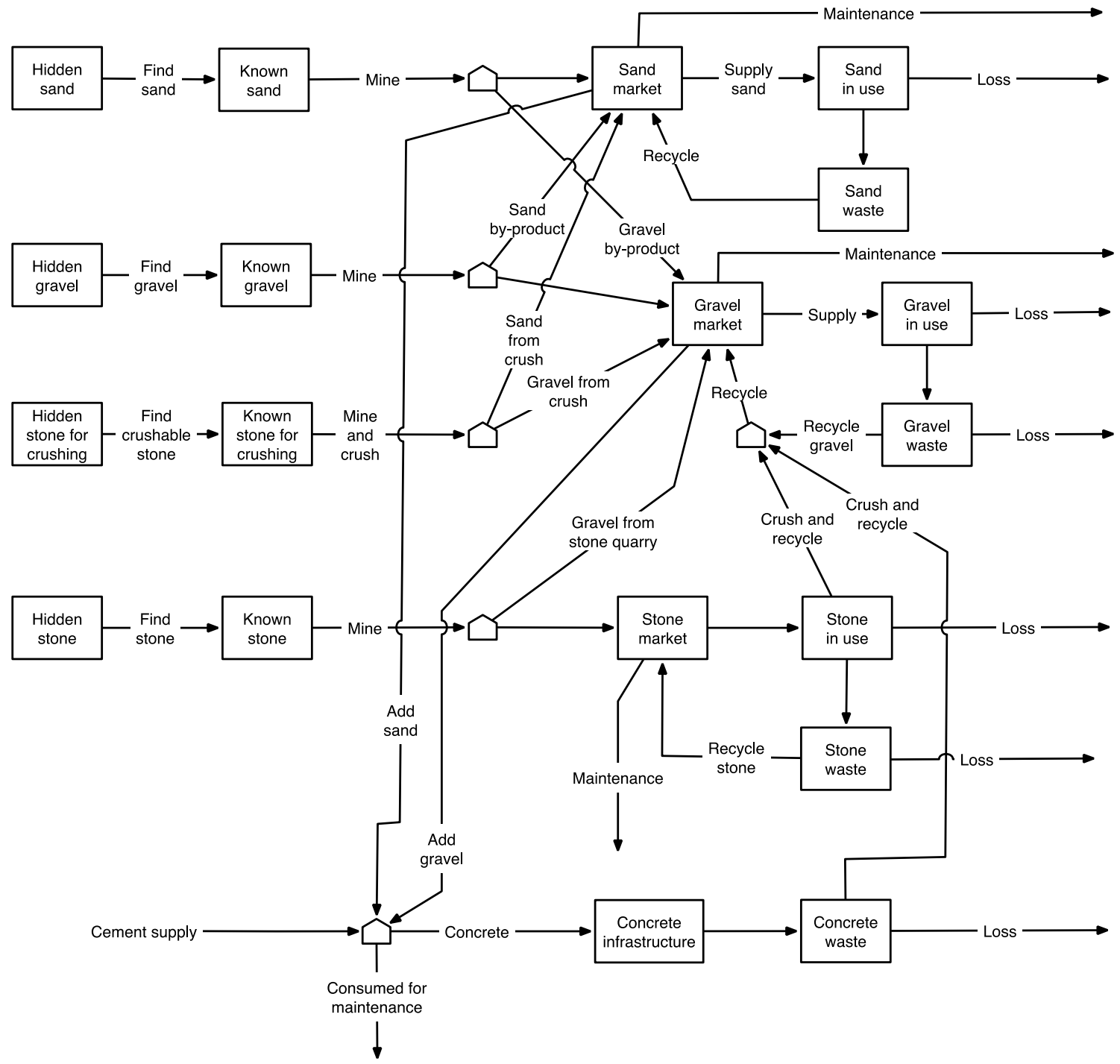

Fig. 1 The flowchart for the sand-gravel-stone (SGS) model. Maintenance flow is assumed to be the replacement for lost material and thus do not add to stock-in-use. Known corresponds to known reserves. All known plus all hidden corresponds to total resources 
(b) In society, we distinguish two above-ground stocks

(i) Gravel in trade market

(ii) Gravel stock-in-use in society

3. Stone for crushing to sand and gravel

(a) Mineable stocks

(i) Known stone for crushing

(ii) Hidden stone for crushing

4. Cut stone for construction, with gravel and sand as byproducts

(a) Mineable stocks

(i) Known stone

(ii) Hidden stone

(b) In society, we distinguish two above-ground stocks

(i) Stone in trade market

(ii) Stone stock-in-use in society

5. Sand, gravel and stone embedded into concrete structures, with gravel as by-product from infrastructure demolitions

(a) In society, we distinguish two above-ground stocks

(i) Sand, gravel, stone and concrete embedded into concrete infrastructures in use in society

(ii) Concrete structure waste from demolishing old structures

This makes a model with 16 linked material stocks, resulting in a system of 16 linked differential equations to be solved. The mining activity is price driven, the price is the market price. Figure 2 shows the flowchart used for the SGS model. Figure 3 shows the price-extraction driving mechanism used in the SGS model. In the model, the market price is set twice every week throughout the simulation. The extraction is in the real world driven by operations profit. This implies that the main driver is the difference between the income from material sales (market price times shipped amount) and the extraction cost. The cost is estimated as extracted amount times the total cost, where the total cost is made up of three components; labour cost, capital expenses costs and energy costs. We have tried this out (Fig. S2 in the supplementary material), as well as a simpler model where we use the price as a proxy for the profit (Fig. 3). Both approaches work well. The extraction for sand, gravel and cut stone also competes with recycling for sand, gravel and cut stone, mostly on a cost basis (Fig. 3).

Figure S1 in the appendix shows the WORLD6 model in outline, and Fig. 4 shows the STELLA model diagram for the SGS model. The SGS model uses a 4-step Runge-Kutta integration method, with a 1/100-year time-step (3.6 days).

In the model, we have assumed that sand and gravel stay 100 years in the infrastructure before the structure is destroyed, based on an evaluation of research literature (Hsu 2009; Korre and Durucan 2007). For cut stone we have assumed that the residence time in society is 100 years. The average lifetime on a concrete infrastructure unit is set to 60 years, based on data from United States, Germany and China.

The SGS model was embedded into the WORLD6 model (see supplementary material, Fig. S1 and S2). In the model, the profit is generated by sales to the market, but reduced with extraction costs and prospecting costs. There are three reinforcing loops in the system. The reinforcing loop marked as R1 in Fig. S2 is driven by the profits-extraction-supply loop. The reinforcing loop R3 is driven by the supply-market, taken from market-society-demolish-recycle loop. The most important balancing loops; B in Fig. 3 are two, the first when the known reserves become depleted, the other when the hidden resources become exhausted and the known reserves can no longer be supplemented with new material. The final loop is when the waste has been exhausted and the last resource runs out. Price is calculated internally in the model as a result of the feedbacks illustrated in Fig. S4 and S5 in the supplementary material. Three parameters intervene to create price dynamics: the effect of market volume on price, and the effect of price on supply, demand and recycling. In the model used, a simplified version of the model shown in S2 in the supplementary materials was used, this is shown in Fig. 3. The characteristic curves for how this is expressed are shown in Fig. S4 and S5 in the supplementary material. The material mining rate was estimated with the following equation:

$r_{\text {mining }}=k_{\text {mining }} \times m_{\text {known }}^{n} \times f($ price $) \times g(\mathrm{~T})$,

where $r$ is the rate of mining, $k$ is the rate coefficient and $m$ is the mass of the ore body, and $n$ is the mining order. The mining order depends on the difficulty of access, and the access or the technological capacity is the main limiting factor. When extraction capacity is the limiting factor for extraction it becomes zeroth order, when the resource availability limits, depending on the geometry $n$ will be in the range $0-7-1$. $\mathrm{f}$ (price) is a feedback function of price, increasing mining at higher extraction profits and lowering it at lower metal prices (see the causal loop diagram in Fig. 3). $g(\mathrm{~T})$ is a technology factor accounting for the invention of technologies used in efficient mining, refining and extraction of metal. We have chosen to set the mining order at $n=1$ as most materials are extracted in open pit mining. The rate coefficient is modified with ore extraction cost and ore grade. There are many different definitions of recycling available (Graedel and Allenby 2003; UNEP 


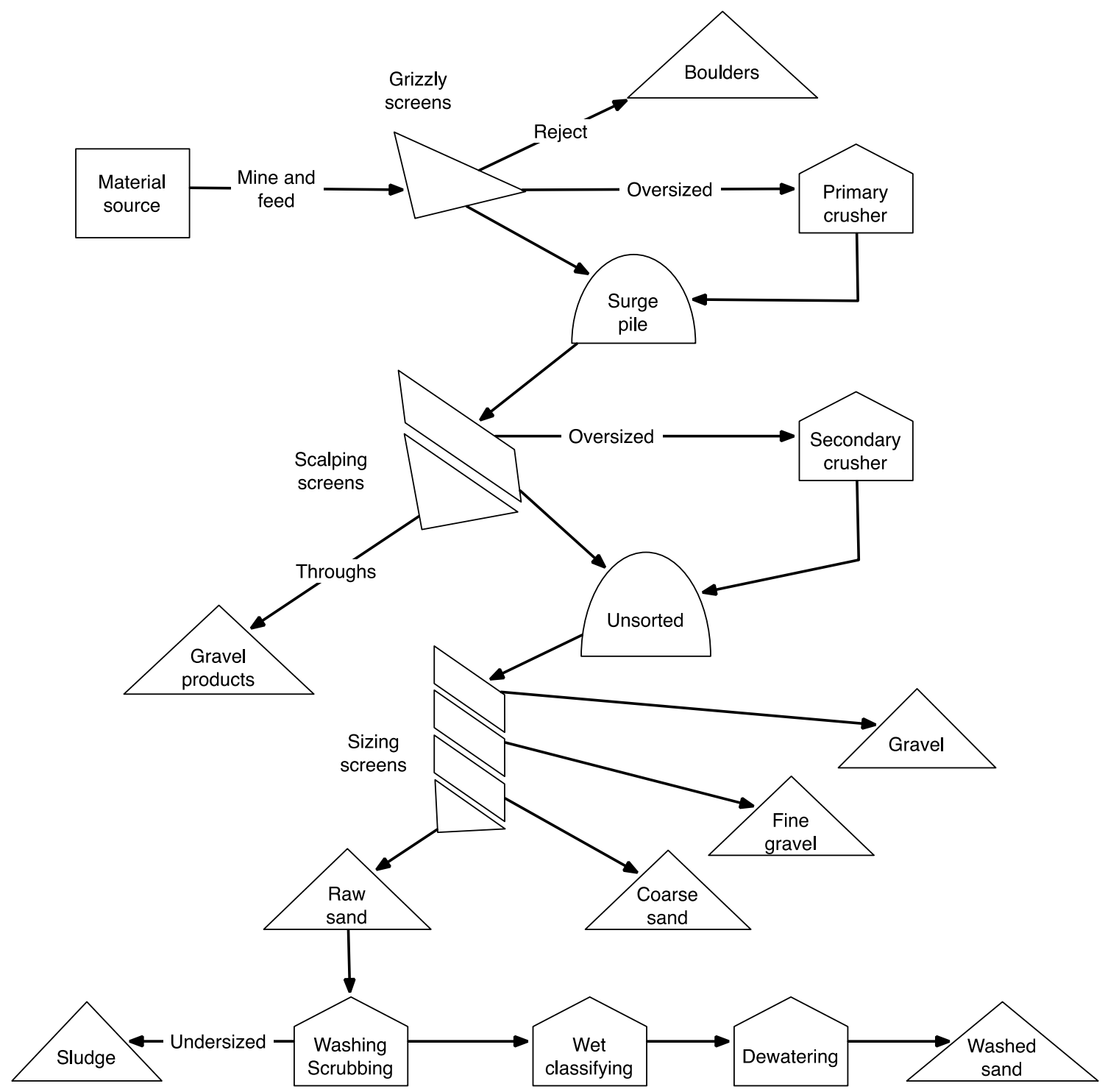

Fig. 2 In the model, crushed stone is processed to sand and gravel. The simple flowchart for aggregates processing from mixed substrate to sand fractions and gravel products in a typical industrial operation is shown

2011). For the purpose of clarity, the recycling fraction displayed in the "Results" section was calculated as follows in this study:

Recycling fraction

$$
=\frac{\text { Flow of recycled metal }}{\text { Supply from primary extraction }+ \text { Flow of recycled metal }} \text {. }
$$

The cost of the mining and extraction operation is mainly determined by two important factors beside cost of investments, the energy price and the ore grade. The size of the extractable ore body is determined by the rate of extractions $\left(r_{\text {mining }}\right)$ and the rate of prospecting $\left(r_{\text {discovery }}\right)$ :

$\frac{d m_{\text {known }}}{d t}=-r_{\text {mining }}+r_{\text {discovery }}$.
The resource discovery is a function of how much prospecting we do and how much there is left to find. The amount hidden reserve ( $\left.m_{\text {hidden }}\right)$ decreases with the rate of discovery. The rate is first order as prospecting is threedimensional by drilling. The driving mechanism of mining comes from profits and availability of a mineable resource used in the model. The rate of discovery is dependent on the amount sand, gravel or stone hidden $\left(m_{\mathrm{H}}\right)$ and the prospecting coefficient $k_{\text {prospecting }}$. The prospecting coefficient depends on the amount of effort spent and the technical method used for prospecting.

$\frac{d m_{\text {hidden }}}{d t}=-r_{\text {discovery }}=-k_{\text {prospecting }} \times m_{\text {hidden }}$. 


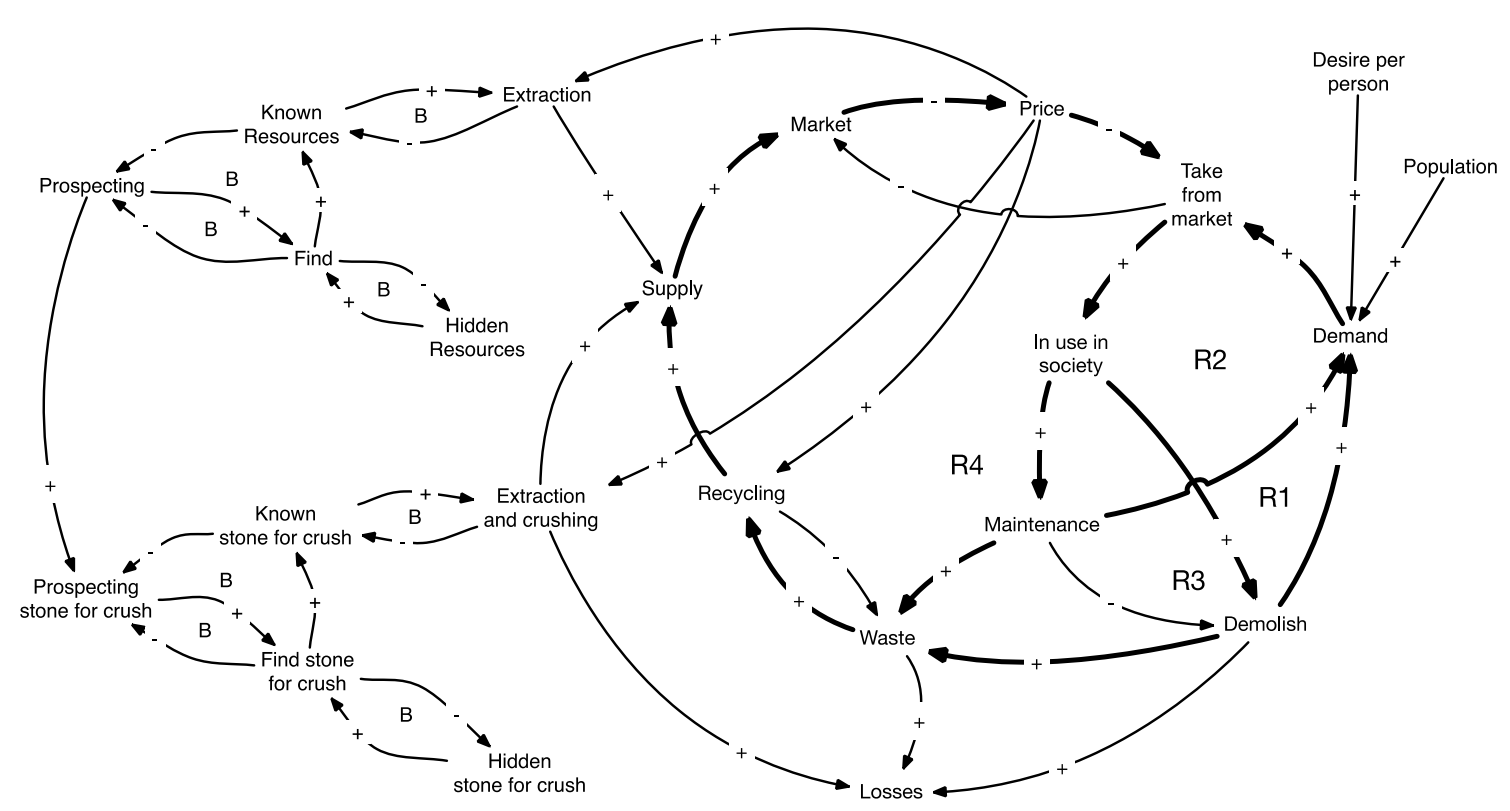

Fig. 3 The basic causal loop diagram applied for the simplified SGS model. The causal loop diagrams for sand, gravel, stone for crushing and cut stone were linked as shown in the flow chart of Fig. 1. The actual model consists of four such coupled causal loop diagrams for sand, gravel, crushed stone and cut stone as Fig. 1 will demand

In the model, crushed stone is processed to sand and gravel. The yield is determined by the following equation:

$r_{\text {product }}=Y_{\text {product }} \times r_{\text {feed }}$,

And for the recycling from stock-in-use in society, the following equation was used:

$\frac{d m_{\text {society }}}{d t}=-\frac{1}{t_{\text {society }}} \times m_{\text {society }}$,

where $t_{\text {society }}$ is the average retention time in society.

$r_{\text {recycling }}=x_{\text {recycling }} \times r_{\text {society outflow }} \times g($ price $)$

where $x_{\text {recycling }}$ is the fraction of the flow out of stock-in-use that is recycled. $g$ (price) is a feedback function, increasing recycling when the commodity market price increases, improving recycling profits (see Sverdrup et al. 2014a). A simple flowchart for crushed stone to general aggregates processing to sand fractions and gravel products is shown in Fig. 5. The diagram shows the process in far more detail than actually pictured in this flow chart. The parameterization of the significant feedbacks used in the SGS model, has been shown in the supplementary material. Table 1 shows the base parameter settings of the model. These parameters define the equation coefficients in the equations given above. The parameters have been set using generic extraction rate coefficients for the different processing rates (Lewis and Clark 1964; Pohl 2011; Darling et al. 2011).
(Fig. S3 in the supplementary material). The bold arrows show the reinforcing. The reinforcing loops $(R)$ keep the system running. The balancing loops $(B)$ act as brakes in the system. The system is driven by demand from general consumption, demolition and maintenance $(R 1-R 2)$ and income through price and pushed by demand $(R 3-R 4)$

Other coefficients were taken from Graedel and Allenby (2003). Table 2 shows the typical composition of concrete. The use of concrete is an important driver of sand, gravel and stone demand. Gravel use for concrete is 4.6 times the weight of the cement and sand use for concrete is about three times the weight of the cement used.

\section{Demand}

The demand was modelled based on a number of parameters and their values drawn from a number of references (Bolen 2011; Distelkamp et al. 2010; Korre and Durucan 2007; Kostka 2011; Krausmann et al. 2009; Merwede 2014, Oijens 2014; Robinson and Brown 2002; Gutowski et al. 2013; Chilamkurthy et al. 2016). The following parameters were evaluated for setting the demand:

- World cement production, which correlates straight to world construction activity and infrastructure maintenance. Cement demand per person and year follows a pattern with increasing demand during the transition to industrial society with a peak and a decline down to a maintenance level. This is paralleled by the demand development for iron and steel (Cullen et al. 2012; Giurco et al. 2013; Hu et al. 2010; Moynihan and Allwood 2012; Pauliuk et al. 2012; 2013; Stanway 2014; OSS 2014). The cement demand per capita has peaked and declined in most of the industrial countries, China 


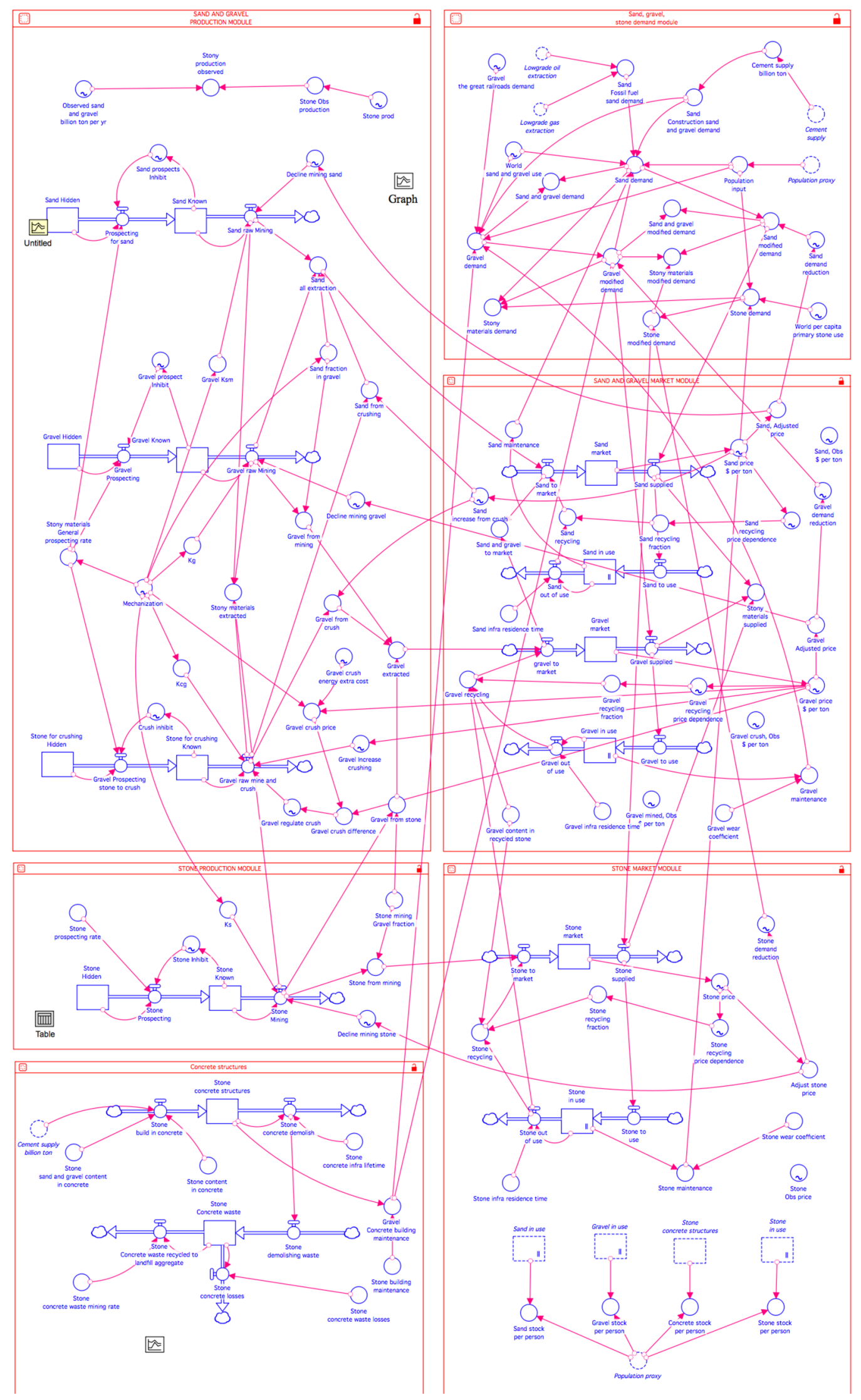

Fig. 4 The sand-gravel-stone (SGS) model, in the STELLA modelling environment 


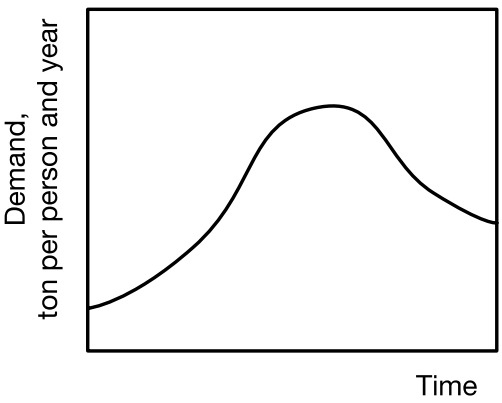

Fig. 5 The demand per person follows a typical pattern with rise, peak and decline to a maintenance level. Most industrialized countries are in the decline to maintenance phase, whereas developing countries are on the rise or close to the peak, depending on what stage they are in their development

and India are in their major transitional stages now, and Africa is about to start. Cement demand is taken from another part of the WORLD6 structure.

- The global expansion of roads and railroads during 1850-1960 used large amounts of gravel. It is given to the model as an exogenous input curve.

- Maintenance of stony material-containing infrastructures in use in society. This is based on an annual decay of the stock-in-use in society; sand, gravel, stone and embedded in concrete.
- World fracking activity for oil and natural gas extraction, dominated by use in North America. Fracking is a way to extract oil and gas from deposits where these are not otherwise extractable. The ground is hydraulically fracked, expanded and the cracks propped open using sand. In the United States of America, fracking takes $50-60 \%$ of the domestic sand demand. Fracking activity is generated inside the energy module in WORLD6 as a part of oil and natural gas production.

- Global general consumption patterns from new construction in diverse infrastructures, replacement construction, sand and gravel as volume filler in polymers and other materials.

This is taken together into a general equation that has the following shape as in Eq. 8:

$D=k_{1} \times r_{C}+k_{2} \times r_{F}+k_{3} \times r_{R}+k_{4} \times r_{F F}+r_{M}+k_{5} \times E_{A} \times N$,

where $D$ is the demand, $r_{\mathrm{C}}$ is the rate of cement production, $r_{\mathrm{R}}$ the rate of gravel use for roads and railroads, $r_{\mathrm{FF}}$ the rate of fossil fuel production using sand, $r_{\mathrm{M}}$ is the rate of sand, gravel or cut stone use for the maintenance of stony material infrastructures, $k_{1}, k_{2}, k_{3}, k_{4}, k_{5}$ are stony material use coefficients calibrated to the year 2000 for the specific commodity or activity, $E_{\mathrm{A}}$ is economic affluency and $N$ is the global population in number of persons. The numbers to
Table 1 Base parameter settings of the rate equations in the SGS model
Table 2 Typical composition of concrete showing the importance of sand and gravel in construction

\begin{tabular}{lllll}
\hline Parameter & Sand & Gravel & $\begin{array}{l}\text { Stone for crushing to } \\
\text { sand and gravel }\end{array}$ & $\begin{array}{l}\text { Stone for } \\
\text { building }\end{array}$ \\
\hline Mining rate coefficient, fraction $\left(k_{\text {mining }}\right)$ & 0.025 & 0.02 & 0.02 & 0.015 \\
Mining rate order $(n)$ & 1 & 1 & 1 & 1 \\
Prospecting coefficient, fraction $\left(k_{\text {prospecting }}\right)$ & 0.005 & 0.005 & 0.03 & 0.035 \\
Base recycling fraction, $\left(x_{\text {recycling }}\right)$ & 0.05 & 0.05 & - & 0.1 \\
Society retention time, years, $\left(t_{\text {society }}\right)$ & 100 & 100 & - & 100 \\
Yield gravel in product, fraction, $\left(Y_{\text {sand }}\right)$ & 0 & 0.85 & 0.9 & 0.5 \\
Yield sand in product, fraction, $\left(Y_{\text {gravel }}\right)$ & 0.85 & 0.15 & 0.1 & 0 \\
Yield stone in product, fraction, $\left(Y_{\text {stone }}\right)$ & 0 & 0 & 0.25 & 0.75 \\
Yield in stone recycling & 0 & 0.5 & 0 & 0.5 \\
\hline
\end{tabular}

The values were taken from estimates in the available scientific literature

\begin{tabular}{lllll}
\hline Material & $\begin{array}{l}\text { \% Volume } \\
\text { content }\end{array}$ & $\begin{array}{l}\text { Specific material } \\
\text { density }\left(\mathrm{kg} / \mathrm{m}^{3}\right)\end{array}$ & $\begin{array}{l}\text { \% Weight con- } \\
\text { tent of concrete }\end{array}$ & $\begin{array}{l}\text { \% Weight content of aver- } \\
\text { age reinforced materials in } \\
\text { buildings }\end{array}$ \\
\hline Sand & 26 & 2700 & 31 & 30 \\
Gravel & 41 & 2700 & 49 & 48 \\
Portland cement & 11 & 2200 & 12 & 11 \\
Water & 16 & 1000 & 7 & 6 \\
Air & 6 & 1 & 0 & 0 \\
Reinforcement iron & - & 5500 & - & 3 \\
\hline
\end{tabular}

The values were taken from estimates in the available scientific literature 
calibrate this relationship came from a number of sources, exemplified by Gutowski et al. (2013), Chilamkurthy et al. (2016) and CemNet (2014) as well as commercial market analysis such as those referred to by NewsChannel1 10 (2014). The maintenance demand for material is calculated as follows:

$r_{\mathrm{M}}=k_{\mathrm{M}} \times M_{\mathrm{i}}$,

where $k_{\mathrm{M}}$ is the decay rate of the infrastructure and $M_{\mathrm{i}}$ is the amount of sand, gravel or cut stone in the infrastructure. An inherent assumption is that the decay of the stock-inuse is compensated for by maintenance. When the lifetime of an infrastructure is passed, it is demolished. The average lifetime is set at 100 years for sand and gravel in infrastructures and at 200 years for cut stone. We have also looked at the retention times for iron and steel in buildings, giving indications for concrete and stony materials (Cullen et al. 2012; Giurco et al. 2013; Hu et al. 2010; Moynihan and Allwood 2012; Pauliuk et al. 2012, 2013; Stanway 2014). The resulting demand is shown in Fig. S3 for sand and gravel combined and for cut stone.

\section{Input Data}

The input data in terms of resource size, mining rates and other key parameters were quite difficult. Large parts of the sand, gravel and stone production are outside the official economy or in a grey zone, and only partially represented in the public statistics and UN or USGS databases. There is not much data available, and what is available is very uncertain. No good global synthesis is available. We have pulled together what we could find in the scientific literature, in corporate brochures and branch organization websites, and made a synthesis of that to our best estimate. Tables 1, 2, 3 and 4 show what we could find.

\section{Results}

\section{Reserves and Resources}

There are no published reserve and resource estimates of sand, gravel and quality stone for construction at the global scale, thus we can give no proper reference for it. However, estimates were made anyhow, based on the available information (Singer 1993, 1995, 2007, 2010, 2011, 2013; Harben and Kuzwart 1996; Chen et al. 2006; Kogel et al. 2006; Korre and Durucan 2007; Bolen 2011; Velegrakis et al. 2010; Kostka 2011; Maps of the World 2012; Moll et al. 2002; Krausmann et al. 2009; Langer 2011; Bliss et al. 2012; Merwerde 2014). The resources are hypothetically huge, but a large portion are economically and geographically unavailable because of lack of transport infrastructure or being located unavailable by occurring in built-up areas, with other types of major infrastructure, or conflicting with agricultural use. Further significant amounts of sand and gravel are located in protected areas and natural reserves and are physically, technically or logistically challenging to extract. Thus, a significant amount of the resources is currently out of reach because of difficulties of extraction, remoteness, conflicting land-use and significant parts are socially unavailable. The available resources have thus been estimated based on the available information. If we assume that the materials are exploited at a rate of $2-3 \%$ of known reserves, this suggests reserves of about 1.6-2.5 trillion ton. Resources are at about five times known reserves for many other resources, and adopting this ratio for sand, gravel and rock materials suggests an extractable resource of about 8-12.5 trillion ton. Table 2 shows an overview of primary and secondary mining of resources. Table 3 shows the typical composition of concrete. We have assumed that $1 \mathrm{~km}^{3}$ of calcite limestone is 2.7 billion ton of stone. Yield
Table 3 Overview of primary and secondary mining of resources

\begin{tabular}{|c|c|c|c|c|}
\hline Material & $\begin{array}{l}\text { URR, available for } \\
\text { extraction, trillion ton }\end{array}$ & $\begin{array}{l}\text { Dependent material, second- } \\
\text { ary production }\end{array}$ & Yield \% & $\begin{array}{l}\text { Production } \\
\text { 2012, million } \\
\text { ton/year }\end{array}$ \\
\hline \multirow{7}{*}{$\begin{array}{l}\text { Silicate-based } \\
\text { stony materials }\end{array}$} & 12 & Gravel & $60-80$ & 2000 \\
\hline & 125 & Crushed stone & $60-80$ & 4920 \\
\hline & \multirow[t]{2}{*}{12} & Cement-sand & 50 & 3600 \\
\hline & & Sand (excluding cement) & 80 & 1300 \\
\hline & 42 & Cut stone & $30-50$ & 70 \\
\hline & 1000 & Rubble material & $80-100$ & 8000 \\
\hline & 1191 & Sum & & 15,000 \\
\hline \multirow[t]{4}{*}{ Limestone } & 10 mill km $\mathrm{km}^{3},>80 \%$ & Cement and mortar & $50-80$ & 3,930 \\
\hline & 20 mill km ${ }^{3}, 80-50 \%$ & Limestone gravel material & $60-80$ & 1700 \\
\hline & 20 mill km ${ }^{3}, 50-20 \%$ & Limestone & 50 & 12,000 \\
\hline & 100 mill km³,$<20 \%$ & Limestone & 25 & $?$ \\
\hline \multicolumn{4}{|c|}{ Sum all sorts of stony materials, billion ton per year } & 52,520 \\
\hline
\end{tabular}

Amounts in billion ton per year. The values were taken from estimates in the available scientific literature 
Table 4 Ultimately recoverable resource estimates for the input data to the SGS model

\begin{tabular}{lllll}
\hline Material & $\begin{array}{l}\text { Yield grade of material \% of the exca- } \\
\text { vated weight becoming product }\end{array}$ & \multicolumn{2}{l}{$\begin{array}{l}\text { Billion ton of stone material extractable as } \\
\text { final useful product }\end{array}$} \\
\cline { 3 - 5 } & & Hidden & Known & URR \\
\hline Sand & 80 & 12,000 & 2 & 12,050 \\
$\begin{array}{l}\text { Gravel } \\
\begin{array}{l}\text { Stone to crush for } \\
\text { gravel and sand }\end{array}\end{array}$ & 60 & 12,000 & 100 & 12,100 \\
$\begin{array}{c}\text { Stone to cut for } \\
\text { construction }\end{array}$ & $30-50$ & 120,000 & 5000 & 125,000 \\
\hline
\end{tabular}

The values were taken from estimates in the available scientific literature is the \% weight of the content that ends up as final product. Table 4 shows the Ultimately Recoverable Resource (URR) estimates for the SGS model. The resources include both known reserves and different types of resources we have reasons to assume are there, but where the exact location and quality has not yet been identified. Only industrial quality for sand and gravel has been considered. For stone, only stone prime quality that can be manufactured to quality building stone has been assessed. For limestone, we have done a very preliminary resource estimate (Bliss et al. 2012). The reserve and resource estimates are shown in Tables 1, 3 and 4. The resources were estimated looking at area underlain by limestone rock.

\section{Model Simulation Results}

The SGS model was run from 1900 to 2200. The results of the SGS model simulations are shown in Figs. 6, 7, 8, 9, 10 and 11 for the time period from 1900 to 2200 under business-as-usual conditions.

Figure 6 shows the model outputs for extraction, supply, recycling for (a) sand, (b) gravel, (c) stone and (d) all stony materials aggregated. The fit for the stone production data to the simulation is $r^{2}=0.52$. Records for validation are available from the USGS database available on the web (USGS 2015). The amounts shown are in billion ton of material, the flows are in billion ton of material per year.

Figure 7 shows the model outputs, market demand and modified demand for (a) sand, (b) gravel, (c) stone for construction and (d) all stony materials aggregated. The circles represent the observed data. The "observed data" in this case are very uncertain estimates, and the available numbers are not properly published and substantiated; thus the validation is only qualitative. The simulations seem to behave correctly; the simulation fits the observations on global total stony materials produced quite well, if we can assume the available data are valid. The simulation of total stony materials extraction seems, likewise, to fit the observations quite well, the correlation coefficient is $r^{2}=0.73$. From the diagram, we can see that whereas we will not run out of physical supply of sand, gravel and stone (hard scarcity), we will encounter increased prices and a peak production followed by a near constant production, suggesting future soft scarcity.

Figure 8 shows the model outputs for the maintenance of the infrastructures built with stony materials. Figure 9 shows the materials (sand, gravel, stone) in use in society (a), known reserves (b) and hidden extractable resources (c). The stock-in-use is important for the maintenance flow. It can be seen that we will not run out of sand, gravel or stone in a very long time. But that if the demand stays on a high level, it will eventually be a finite resource that can be depleted.

Figure 10 shows the model outputs for price in the market, the simulated and observed price for stone, gravel and sand. The comparison with observed data for price shows a satisfactory fit. The results show that the world is not running out of stone, but that we may run out of sand, gravel and cut stone of the right quality for many purposes. The model suggests future increases in price for sand, gravel, crushed aggregates and cut stone. The world market price reconstruction for sand and cut stone is quite successful, for crushed stone to sand and gravel less so, even if the order of magnitude is correct. This is done under the assumption that there is a functioning global market for sand, gravel and cut stone. There is such a global market, but the prices show huge variations locally, depending on transportation costs and local cost conditions. Considering the inherent inaccuracies one would think was in this approach, it is amazing how well the produced amounts and global prices are simultaneously modelled. The prices are expressed as 1998 inflation-adjusted dollars.

\section{Discussion}

\section{The Peak Shape of the Curves}

The curves have a behaviour consisting of a period of strong growth, an end of growth and stabilization at a 

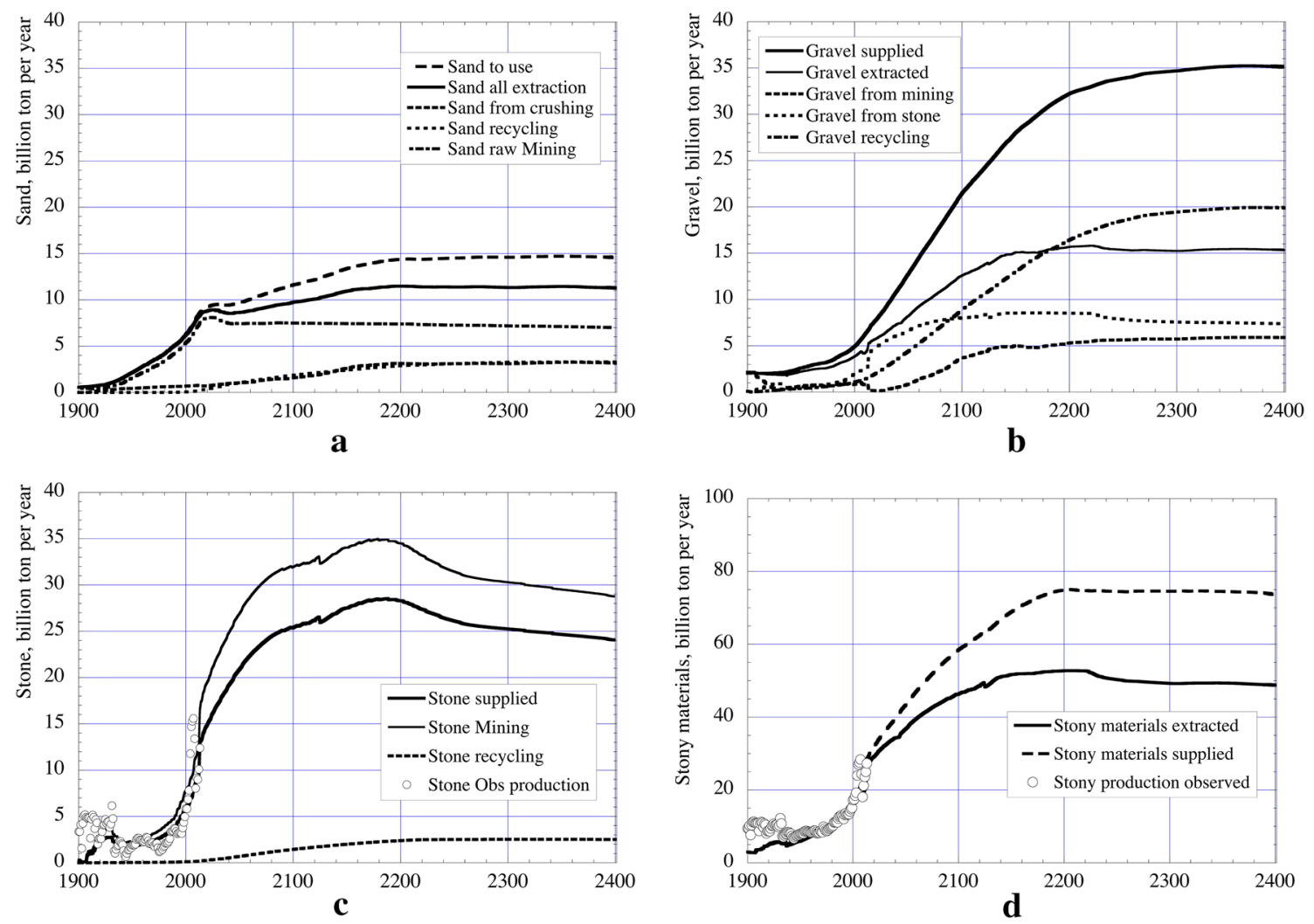

Fig. 6 The model outputs for mining, from crushing and as by-product from sand, gravel, stone or concrete, supply, recycling, for a sand, b gravel, $\mathbf{c}$ stone and $\mathbf{d}$ concrete. The amounts shown are in billion ton of stony material, flows are in billion ton of material per year

stable level. The reason for this is the way demand is driven by population and the typical demand per person and year curve as shown in Fig. 5. Figure 11 shows the material supply expressed as ton per person per year, and as stock-inuse per person. It can be seen that the use per person cannot grow indefinitely. For cut stone, growth will peak about 2020, and sand and gravel around 2055. The following parameters affected the shape of the curve the most:

1. The population over time development, and its general consumption. This is an important determinant for demand.

2. The shape of the demand per person and year curve, and the approach to infrastructural saturation. The shape of this curve was taken from the scientific literature and UNEP reports from the International Resource Panel.

3. The prospecting activity level, determining how fast "hidden" is transferred to "known". As long as prospecting and finding matches the extraction, production can be kept up or grow, if not "known" will decline and extraction with it.
It also shows that 2020 supply level can be kept for a significant long time. Sand, gravel and cut stone run into soft scarcity because of rising prices as the response to increased demand. Cut stone approaches physical scarcity for short periods after 2100. The world will not run out of sand, gravel or cut stone, but high prices will limit demand through feedbacks. The amount of these materials extracted annually are very large, and as the price increases, it will be foreseeable that resources unavailable under present social conditions or restrictions to extraction. These conditions and restrictions may be challenged and brought under pressure to be released for exploitation as the price increases. In the model a technology development curve is used, this was adapted after results like those presented by Gutowski et al. (2013).

\section{Uncertainties and Certainties}

The amounts of sand, gravel and stone on the Earth are truly enormous, but what part of this exists in extractable form is dependent on materials having the desired mechanical or chemical properties. Major uncertainties in the output from the model are associated with the lack of reliable global sand, gravel and stone resource estimates. 

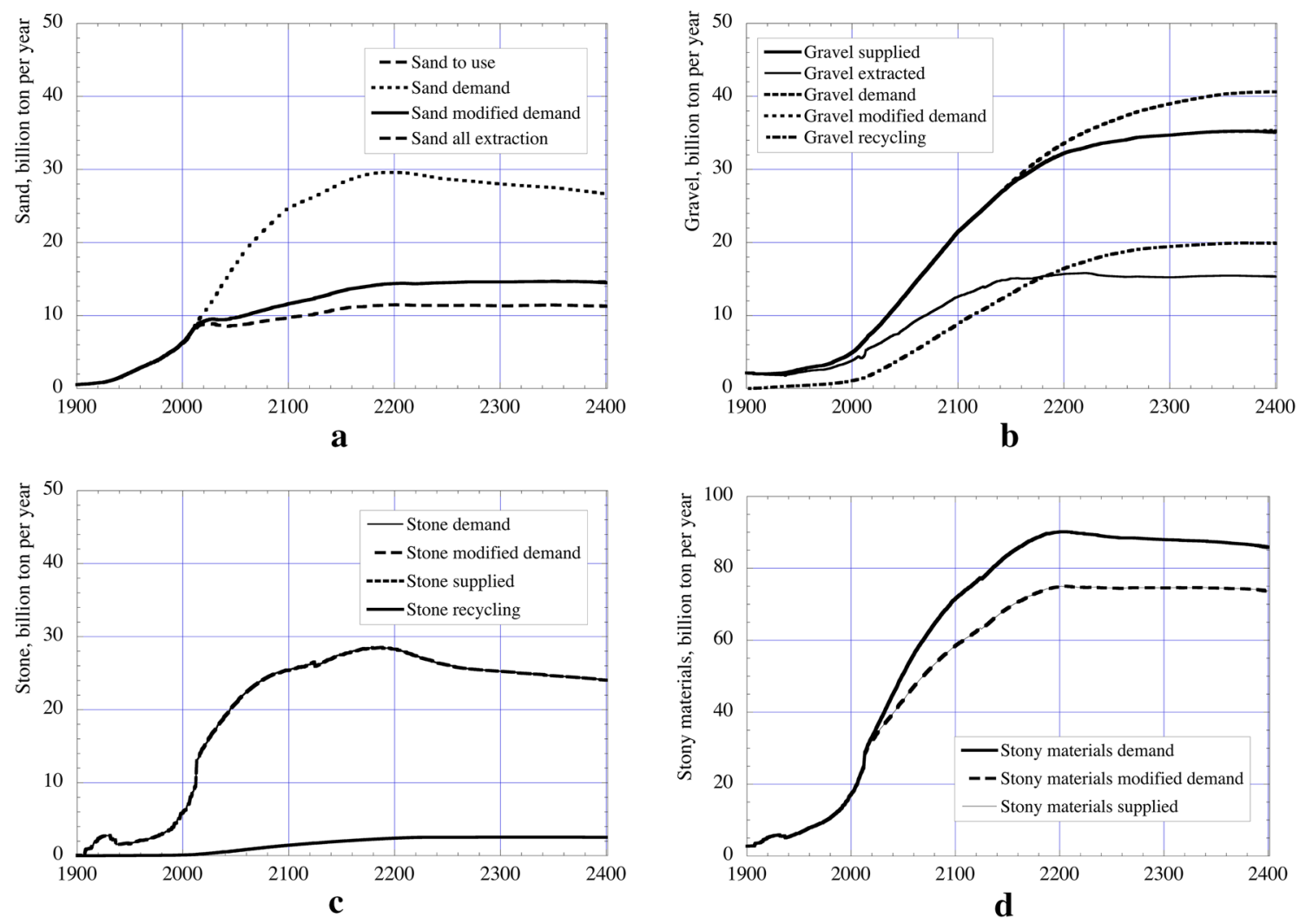

Fig. 7 The model outputs market demand and degree of supply sufficiency a sand, $\mathbf{b}$ gravel, $\mathbf{c}$ stone for construction and $\mathbf{d}$ all stony materials aggregated. In diagram (d), line 5 represents the observed data

that should be ignored after 2015. The amounts shown are in billion ton of material, the flows are in billion ton of material per year

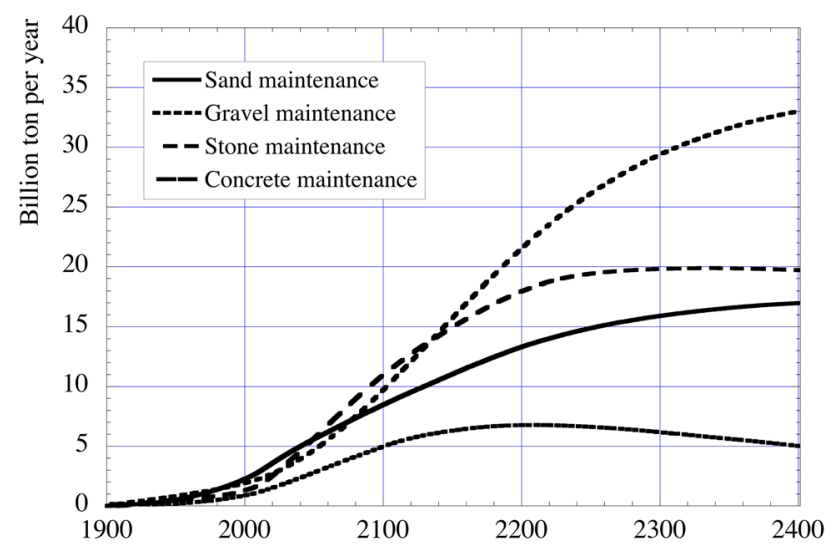

from a social perspective will be highly dependent on social and environmental development. We do not attempt to prognosticate future resource use or availability-we attempt to provide a scenario assessment, based on a business-as-usual run, of potential future resource scarcity horizons. We attempt to do this with a simplified model to obtain a sense of orders of magnitude and relevant times involved. The model was not intended to capture all details, and it seems to work well at the global level.

The only performance measures available for validation are the ability to predict the past mining trajectory, and the market price (Fig. 10) for these commodities. When considering the difficulties in the input data, and the challenge of getting the market response curves correct, the model performs surprisingly well (Figs. 4, 13).

While we can securely assume mass balance principles to be valid at all times which is adding robustness to mass balance-based models like the SGS model, other factors are less straightforward. It appears more than likely that values with regard to landscape, nature conservation, recreation and perceived resource needs and balance and trade-offs between different needs, societal actors and sectors will be significantly different from today in the long perspective 

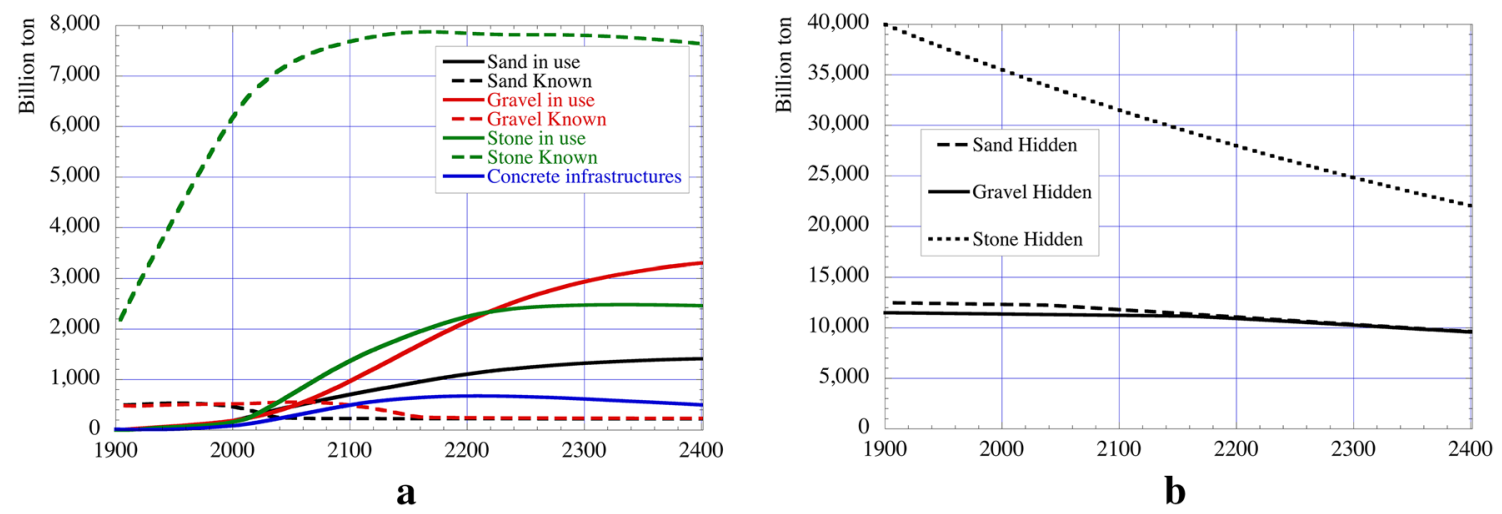

Fig. 9 The model outputs for materials (sand, gravel, stone) as a known reserves and stocks-in-use in society. The flows are in billion ton of material per year. In concrete, the weight of the concrete itself is also included. b Shows the hidden resources declining slowly with time
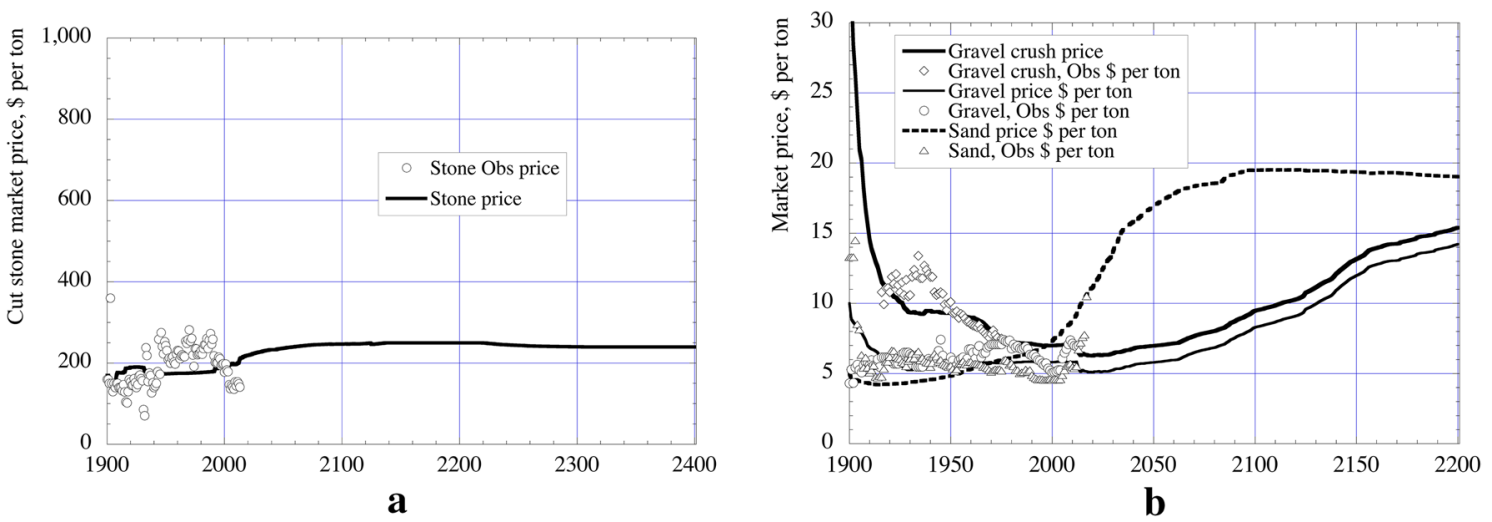

Fig. 10 Commodity market price. The model outputs for the simulated and observed price for stone (a) and gravel and sand (b). The observed price for sand, gravel and stone are shown

and time-frame covered by our calculations. We are not attempting to model such societal change. Technological change (substitution, increased resource efficiency, etc.) will have impact, but probably less so than changes in values, on resource availability as sand, gravel and rock resources to a large degree are used as bulk materials. The apparent model output should be seen as a representation of an illustrative future under assumed "business-as-usual" conditions rather than a projection of a likely future as such. Nevertheless, seen as a scenario, the results allow a better informed discussion about the magnitudes of future resources, their long-term use and sustainability than the alternative of no attempt at assessment.

\section{Testing the Model on Data}

The success when testing the model suggests that the SGS model already has about an adequate level of complexity and that the key parameters seem to have been set at appropriate value. Figures 11 and 12 show the result of the SGS model integrated into the WORLD6 model and tested against observed data on production of sand, gravel and rock materials as reported by the US Geological Survey Minerals database for 2015. The forecasts made with the GINFORS model were also tested (Meyer and Lutz 2007; Meyer et al. 2012). The test shows that the SGS model performs very well within the WORLD6 model, and that the outputs are consistent with the GINFORS outputs. Figure 13 shows a plot of modelled production of rock materials versus observed total rock materials' extraction amounts using the SGS model as a stand-alone model. The plot shows that the model is sufficiently accurate for assessing global production rates. Figure 13 shows the outputs from the SGS model when it is integrated into the WORLD model and tested against data. The correlation between the WORLD6 simulation and the USGS data is $r^{2}=0.76$, which is better than the performance of the SGS model when it is run as a stand-alone model $\left(r^{2}=0.72\right)$. The consistency between the GINFORS forecast and the WORLD6 is $r^{2}=0.98$ (Fig. 13). The test of the SGS incorporated in WORLD6 against the GINFORS model outputs and the 

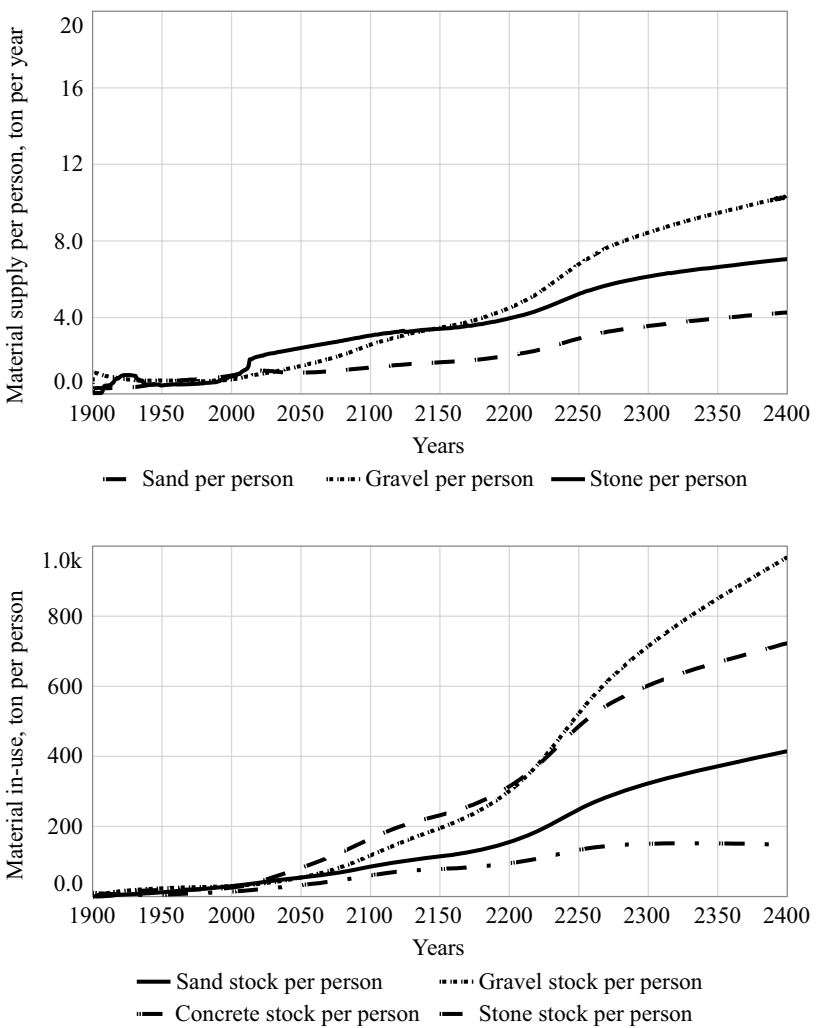

Fig. 11 Material supply expressed as ton per person per year, and stock-in-use as ton per person

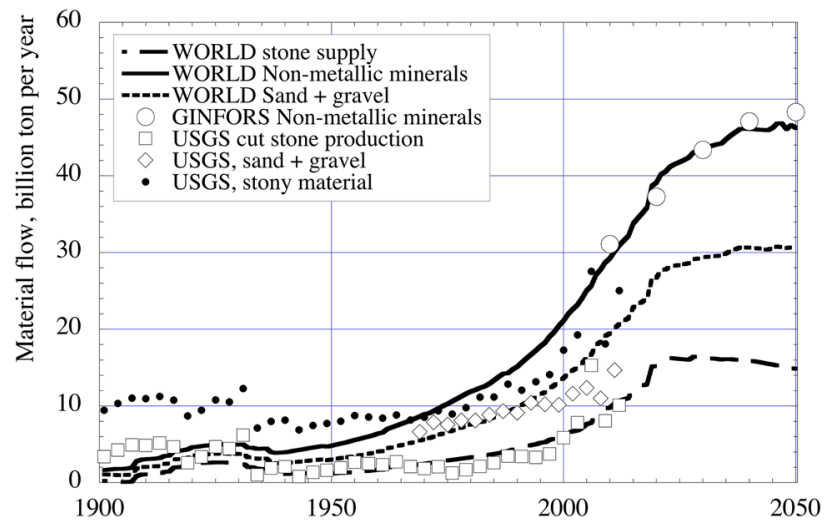

Fig. 12 The SGS model was integrated into the WORLD6 model and tested against observed data on supply to the market as reported by the US Geological Survey Minerals database for 2015. The plot shows that the model is able to reconstruct the right orders of magnitude for the production when compared to data

USGS data pooled together has the correlation coefficient $r^{2}=0.86$.

A successful test of an integrated complex model like the SGS model inside the WORLD6 model on field data, makes the discussion over what could be wrong from a theoretical point of view less relevant, giving more emphasis on simulation performance with respect to testing recorded extraction data. A next step, but outside the scope of this paper, will be to run the model through a number of sensitivity runs in order to assess the robustness and variability of the outputs. At this stage, it is obvious to the user that the results are quite sensitive to the demand created by aggregated per capita consumption as well as by maintenance of built infrastructures. It would be of priority to analyse the effect of different resource magnitudes (varying those shown in Tables 2, 3, 4) and extraction rates (varying those shown in Table 1).

\section{Sand, Gravel and Rock Scarcity}

The used volumes of sand, gravel, crushed rock and stone are truly huge. Extracting, moving, crushing, shaping these materials at the present volumes require large amounts of energy. When energy eventually becomes expensive and/ or transport distances, i.e. transport costs, increase significantly, the price of these products will go up. The curves in Fig. 6 exhibit a rapid growth, stagnation and almost flat development for sand, gravel and stone with time. But from Fig. 9, it appears that even its known reserves may decrease, hidden reserves are far from being exhausted. In fact, they seem to be able to last for several centuries. Hence, on a global scale stone for crushing stone to sand and gravel fractions appears not deplete significantly for the next centuries.

While there is no imminent prospect of stony building materials becoming globally scarce this is unlikely to be the case at other scales. Natural sand and gravel are indeed limited finite resources, and they may be excavated to depletion, in particular at a regional scale around populated centres. Locally, sand and gravel scarcity is already an observable fact (UNEP GEAS 2014; Ashraf et al. 2011; Ooijens 2014; Morrow 2011; OSPAR 2003; Ravishankar 2015), putting demand pressure for long-distance supply into the global markets, and potentially causing environmental impacts where it is extracted.

The primary substitute for natural sand and natural gravel is industrially produced sand and gravel from crushed stone and rock. This is nearly inexhaustible from a point of view of having enough raw material, while not necessarily in the longer run as the long-term supply of sand and gravel from crush is likely to be limited by the future energy supply, availability of long range transport, ability to pay, availability of resources from a social context and not only rock quality. Sand, gravel and crushed rock long-distance transportability, between extraction site and final use, is for economical and energy reasons limited - 50 billion ton of stony material cannot be moved without significant use of energy and not without impacts of roads, noise and pollution. As the price increases, the 


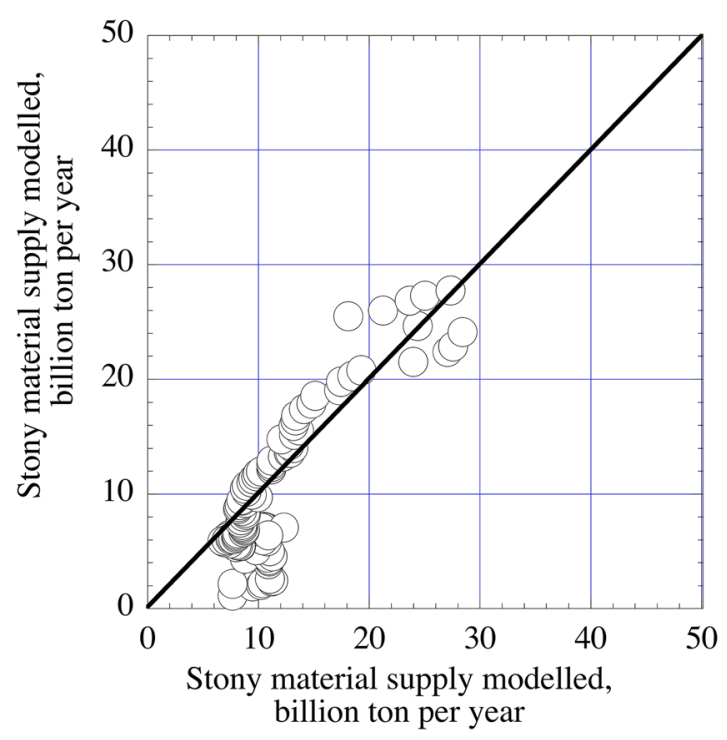

Fig. 13 A simple plot of modelled versus observed total stony material extraction amounts using the SGS model as a stand-alone model is shown in diagram (left). Diagram (right) shows the outputs from

feedback from price tends to reduce demand, thus implying "soft scarcity". In the continuation, the prices may rise even more owing to competition with other land-use, prices for mining rights and further increases in energy pricing, leading to unaffordability; a transition to economic scarcity, rather than physical scarcity. In a distant future, the primary extractable resource may in practical terms end up being exhausted. Recycling rates remain low in the sand, gravel and stone use systems, much because of the low commodity cost. Currently, the drive to recycle for economic reasons is not particularly strong; however, this will change when resource prices increase.

\section{Policy Implications}

Given the long time-perspective of this study and the substantial uncertainties with regard to important data general policy recommendations would be premature. Still, we may speculate based on common sense, generic knowledge and evaluations based on our outputs.

We need to consider that management of the resources in question for practical and economic reasons operates at a regional as well as at a global scale. Scarcity increases efforts of globalization, shifting to other sources of supply and to increased efficiency, minimizing transient stocks. Nevertheless, there is an apparent agreement in the available publications that we are moving towards a possible risk of more widespread sand and gravel soft scarcity, at least regionally.

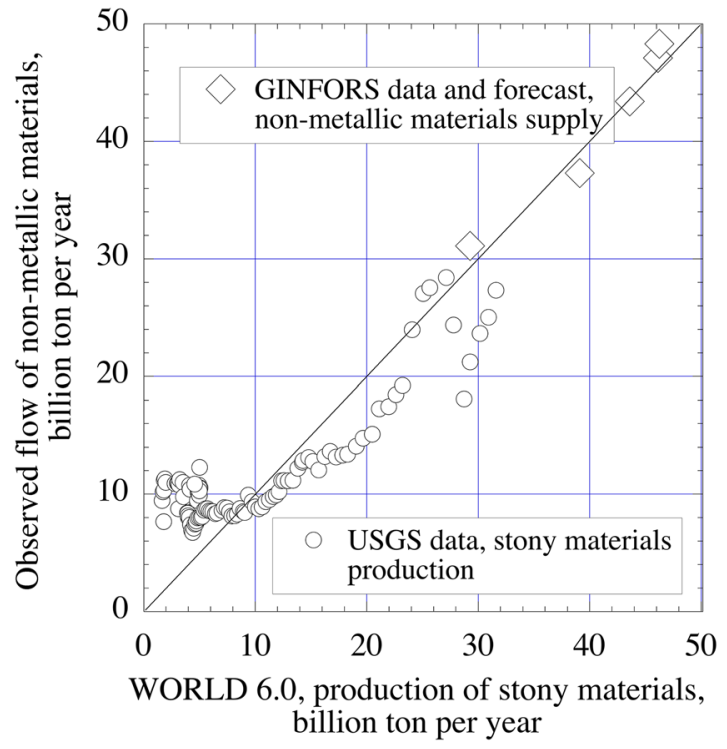

the SGS model when it is integrated into the WORLD6 model and tested against data

We think that increasing prices will drive the market towards more globalization, a process already in progress. The conditions and restrictions imposed on and limiting extraction are often rooted in the local communities and regions. The policy challenges will involve how these different scales interact, and their relative strengths.

We would suggest that there is a need to put some effort into getting better regional overviews of available reserves and resources. Such assessments need to include informal or illegal extraction which currently is omitted from official estimates. Similarly, better data on recycling and re-use of bulk materials are needed.

Further, we would suggest that there is a need to assess the large difference between what is actually present and what may be technically and socially viable to extract, as well as how this relates to the available future energy. The amounts extracted, processed and transported run in the size of 30 billion ton per year, and the amount of energy used in such task is significant.

\section{Conclusions}

The developed model performs well and, given input data constraints and uncertainty, successfully reproduces production and global market price when compared with independently observed data. The modelling of sand, gravel and stone resources have reached a level of complexity with this model where few further improvements 
can be made until better data become available in open scientific sources. At present, this is very limited, making assumptions necessary. The simplifications done to the model from the full concept still retain a good level of performance and show the same dynamics as the full model, but with better stability. For this reason, the simplified version is the best practical modelling option.

The simulation, under assumed business-as-usual conditions, shows that cut stone production will reach a maximum level about 2020-2030 and may slowly decline after that. The cause for this is that demand exceeds extraction as well as slow exhaustion of the known reserves of high-quality stone. Sand and gravel also show peak behaviour and reach their maximum production rate in 2060-2070. The reason for the peak behaviour is partly driven by an expected population maximum in 2065 and later slow decline combined with increasing prices for sand and gravel, limiting the demand.

The developed SGS model appears to perform well enough when compared to observations to justify for it to be included in the WORLD6 model. The outputs from the SGS model when embedded in WORLD6 show a slightly better performance against observed data. The outputs appear to be consistent with the GINFORS forecasts in the interval from 200 to 2050.

While in a global perspective, supply may seem to be inexhaustible and availability is already a growing problem at a local to regional scale, signalling that global trade with sand, gravel and stone will continue to increase. We need better data on production rates, use and recycling to better assess risks of regional scarcity, as well as a model of this kind divided into different regions. The state of the research is at present not at a stage where this is possible without substantial research funding to support it. The SGS model, given better data, could be used for this as it could be down-scaled to regions.

\begin{abstract}
Acknowledgements This study was done as a part of the SIMRESS project (Models, potential and long-term scenarios for resource efficiency), funded by the German Federal Ministry for Environment and the German Environmental Protection Agency (FKZ 371293 102). Other partners to the SIMRESS project are Ecologic Institute, Berlin, Germany (Martin Hischnitz-Garber and Susanne Langsdorf); the Institute of Economic Structures Research, GWS, Osnabrück, Germany (Mark Meyer and Martin Distelkamp); European School of Governance, EUSG, Berlin, Germany. Dr. Ullrich Lorenz is the Project Officer at the German Environmental Protection Agency (UBA). The GINFORS simulations and output tables were done by Martin Distelkamp and Mark Meyer at the GWS.
\end{abstract}

\section{References}

Anthoni JF (2000) Oceanography: dunes and beaches. http://www. seafriends.org.nz/oceano/beach.htm
Aquaknow (2014) Sand mining- the 'high volume-low value' paradox. http://www.aquaknow.net/en/news/ sand-mining-high-volume-low-value-paradox/

Ashraf MA, Maah MJ, Yusoff I, Wajid A, Mahmood K (2011) Sand mining effects, causes and concerns: a case study from Bestari Jaya, Selangor, Peninsular Malaysia. Sci Res Essays 6:1216-1231

Bardi U (2013) Extracted: how the quest for mineral wealth is plundering the planet. The past, present and future of global mineral depletion. A report to the Club of Rome. Chelsa Green Publishing, Vermont, ISBN: 978-1-60358-541-5

Bardi U, Lavacchi A (2009) A simple interpretation of Hubbert's model of resource exploitation. Energies 2:646-661. doi:10.3390/en20300646

Bliss JD, Hayes TS, Orris GJ (2012) Limestone-a crucial and versatile industrial mineral commodity. USGS Fact Sheet 2008-3089

BMI Research (2014) Global industry overview: sand miners on solid ground-October 2014. http://www.mining-insight.com/ global-industry-overview-sand-miners-solid-ground-oct-2014

Bolen WP (2011) Sand and gravel, construction. 2009, Minerals yearbook, update. USGS, Washington, DC, pp 64.1-64.18. Domestic survey data and tables were prepared by H.A. Fatah, M.L. Jackson, and F.H. Morgan, statistical assistants

CemNet (2014) Cement demand. http://www.enr.com/articles/38747pca-forecasts-growth-in-cement-consumption-at-world-ofconcrete-2016, http://www.cemnet.com/Articles/story/153619/ global-cement-2014-outlook.html

Chen BC, Ramakrishnan R, Shavlik JW, Tamma P (2006) Bellwether analysis: predicting global aggregates from local regions. VLDB '06, September 12-15, 2006, Seoul, Korea. Copyright 2006 VLDB Endowment, ACM 1-59593-385-9/06/09

Chilamkurthy K, Marckson AV, Chopperla ST, Santhanam M (2016) A statistical overview of sand demand in Asia and Europe. In: International conference UKIERE CTMC'16, at Goa. https:// www.researchgate.net/publication/309409121_A_statistical_ overview_of_sand_demand_in_Asia_and_Europe

Cullen JM, Allwood JM, Bambach MD (2012) Mapping the global flow of steel: from steelmaking to end-use goods. Environ Sci Technol 46:13048-13055

Darling P et al (eds) (2011) SME mining engineering handbook, 3rd edn. Society for Mining, Metallurgy, and Exploration, Englewood. SBN-13: 978-0873352642\$4

Distelkamp M, Meyer B, Meyer M (2010) Quantitative und qualitative Analyse der ökonomischen Effekte einer forcierten Ressourceneffizienzstrategie. Kurzfassung der Ergebnisse des Arbeitspakets 5 des Projekts "Materialeffizienz und Ressourcenschonung" (MaRess), Ressourceneffizienz Paper 5.2, ISSN 1867-0237, Wuppertal Institute, Wuppertal. http://ressourcen. wupperinst.org/downloads/MaRess_AP5_3_Zusammenfassg. pdf

Giljum S, Hinterberger F, Bruckner M, Burger E, Frühmann J, Lutter S, Pirgmaier E, Polzin C, Waxwender H, Kernegger L, Warhurst M (2000) Overconsumption? Our use of the world's natural resources. CSERI, GLOBAL 2000, friends of the Earth Europe, September 2009

Giljum S, Hinterberger F, Lutz C, Meyer B (2008) Accounting and modelling global resource use: material flows, land use and input-output models. In Suh S (ed) Handbook of input-output economics for industrial ecology. Springer, Dordrecht

Giljum S, Lutz C, Jungnitz A, Bruckner M, Hinterberger F (2011) European resource use and resource productivity in a global context. In: Ekins P, Speck S (eds) Environmental tax reform (ETR). A policy for green growth. Oxford University Press, Oxford

Giurco D, Mohr S, Mudd GM (2013) Resources and supply-demand over the very long term. GSA's 12 . Anniversary annual meeting 
and expo. 39 powerpoint slides. In: Pardee Keynote symposium P12: resourcing future generations, 27-30 October 2013, Denver

Graedel TE, Allenby BR (2003) Industrial ecology, 2nd edn. Pearson Education Inc, AT \& T, Upper Saddle River

Gutowski TG, Sahni S, Allwood JM, Ashby MF, Worrell E (2013) The energy required to produce materials: constraints on energyintensity improvements, parameters of demand. Philos Trans R Soc A 371:20120003. doi:10.1098/rsta.2012.0003

Haraldsson HV, Sverdrup HU (2004) Finding Simplicity in complexity in biogeochemical modelling. In: Wainwright J, Mulligan M. (eds) Environmental modelling: a practical approach. Wiley, Chichester, pp 211-223

Harben PW, Kuzvart M (1996) Industrial minerals-a global geology. Industrial Minerals Information Plc., London

Heinberg R (2001) Peak everything: waking up to the century of decline in Earth's resources. Clairview, Forest Row

Heinberg R (2011) The end of growth. Adapting to our new economic reality. New Society Publishers, Gabriola Island

Hirschnitz-Garber M, Langsdorf S, Sverdrup H, Koca D, Distelkamp M, Meyer M (2015) Integrated modelling for resource policy assessment-the SimRess-project. In: Proceedings of the 2015 word resources forum, 11-15 September, Davos, Switzerland

Horwath A (2004) Construction materials and the environment. Annu Rev Environ Resour 29:181-204. doi:10.1146/annurev. energy.29.062403.102215

Hsu SL (2009) Life cycle assessment of materials and construction in commercial structures: variability and limitations. Master thesis, Department of Civil and Environmental Engineering. (C2010 Massachusetts Institute of Technology

Hu M, Pauliuk S, Wang T, Huppes G, van der Voet E, Müller D (2010) Iron and steel in Chinese residential buildings; a dynamic analysis. Resour Conserv Recycl 54:591-600

Kifle D, Sverdrup H, Koca D, Wibetoe G (2012) A simple assessment of the global long term supply of the rare earth elements by using a system dynamics model. Environ Nat Resour Res 3:1-15. ISSN 1927-0488E-ISSN 1927-0496. doi:10.5539/enrr.v3n1p77

Kogel JE, Trivedi NC, Barker JM, Krukowski ST (eds) (2006) Industrial minerals and rocks, 7th edn. Society for Mining, Metallurgy, and Exploration, Littleton, Colorado

Korre A, Durucan S (2007) Life cycle assessment of aggregates. EVA025-final report: aggregates industry life cycle assessment model: modelling tools and case studies. waste and resources action programme. The Old Academy. 21 horse fair, Banbury

Kostka S (2011) Sand, gravel, and crushed stone: the world's building blocks. 26 ppt presentation. Minnesota Department of Natural Resources. http://www.d.umn.edu/prc/MMEW/2011\%20 MMEW\%20PPTs/Aggregate\%20SK.pdf

Krause C, Diesing M, Arlt G (2010) The physical and biological impact of sand extraction: a case study of the western Baltic Sea. J Coastal Res 51:215-226

Krausmann F, Gingrich S, Eisenmenger N, Erb K-H, Haber H, Fischer-Kowalski M (2009) Growth in global materials use, GDP and population during the twentieth century. Ecolog Econ 68:2696-2705

Langer W (2002) Managing and protecting aggregate resources. Open-file report 02-415. USGS Denver, Colorado

Langer WH (2011) A general overview of the technology of in-stream mining of sand and gravel resources, associated potential environmental impacts, and methods to control potential impacts. Open-file report OF-02-153. USGS Washington, DC

Langer W (2014) Aggregates; constructions and and gravel. Chapter $14 ; 159-170$ report. http://www.segemar.gov.ar/bibliotecaintemin/LIBROSDIGITALES/Industrialminerals\&rocks7ed/ pdffiles/papers/014.pdf

Lewis RS, Clark GB (1964) Elements of mining, 3rd edn. Wiley, Hoboken, ISBN 13: 978-0471533313\$4
Maps of the World (2012) World sand and gravel producing countries. http://www.mapsofworld.com/minerals/world-sand-and-gravelproducers.html

Meadows DL, Behrens WW III, Meadows DH, Naill RF, Randers J, Zahn EKO (1974) Dynamics of growth in a finite world. WrightAllen, Massachusetts

Meadows DH, Meadows DL, Randers J, Behrens W (1972) Limits to growth. Universe Books, New York

Meadows DH, Randers J, Meadows D (2005) Limits to growth. The 30 year update Universe Press, New York

Merwede, Ooijens S (2014) Update of sand and gravel resources and extraction worldwide. 28 page slideshow. http://www.metso. com/miningandconstruction/MaTobox7.nsf/DocsByID/A9260 A9C59A15848C2257D87004694A7/\$File/Manufactured\%20 Sand.pdf

Meyer B, Lutz C (2007). Resource productivity, environmental tax reform and sustainable growth in Europe. The GINFORS model. Model overview and evaluation. http://www.petre.org.uk/pdf/ sept08/petrE_WP3\%202\%20Ginfors.pdf, petrE; (see http://www. petre.org.uk/papers.htm) is part of the Anglo-German Foundation research policy initiative: Creating sustainable growth in Europe, p 21. http://www.agf.org.uk/currentprogramme/CreatingSustainableGrowthInEurope.php

Meyer B, Meyer M, Distelkamp M (2012) Modeling green growth and resource efficiency: new results. Miner Econ 24:145-154

Moll S, Bringezu S Femia A, Hinterberger F (2002) Ein Input-Output-Ansatz zur Analyse des stofflichen Ressourcenverbrauchs einer Nationalökonomie. Ein Beitrag zur Methodik der volkswirtschaftlichen Materialintensitätsanalyse. In Hinterberger F, Schnabl H (eds) Arbeit-Umwelt-Wachstum. Nachhaltigkeitsaspekte des sektoralen Strukturwandels. Book on Demand, Norderstedt

Morrigan T (2010) Peak energy, climate change and the collapse of global civilization. The current peak oil crisis. 2nd edn. Global climate change, human security and democracy, orfalea center for global and international studies, University of California, Santa Barbara

Morrow D (2011) Why manufactured sand? Results. Minerals and Aggregates 26-27

Moynihan MC, Allwood JM (2012) The flow of steel into the construction sector. Resour Conserv Recycl 68:88-95

Nakamura S, Nakajima K, Kondo Y, Nagasaka T (2007) The waste input-output approach to materials flow analysis: concepts and application to base metals. J Ind Ecol 11:50-63

NewsChannel110 (2014) Sand assessments referred to here: global sand screen market supply-demand, industry research, end user application and regional analysis to $2027 \mathrm{http} / / / \mathrm{www}$. newschannel10.com/story/33312456/global-sand-screen-market-supplydemand-industry-research-end-user-application-and-regionalanalysis-to-2027

Nickless E, Bloodworth A, Meinert L, Giurco D, Mohr S, Littleboy A (2014) Resourcing future generations white paper: mineral resources and future supply. International union of geological sciences.

Ooijens S (2014) Update of sand and gravel resources and extraction worldwide. IHC, Merwede. https://www.ciria.org/CMDownload. aspx?ContentKey=a9eebdd5-025a-4b12, http://www.metso. com/miningandconstruction/MaTobox7.nsf/DocsByID/A9260 A9C59A15848C2257D87004694A7/\$File/Manufactured $\% 20$ Sand.pdf

OSPAR (2003) Agreement on sand and gravel extraction, OSPAR agreement 2003-2015. http://www.ospar.org/documents/dbase/ decrecs/agreements/03- 05e_Reporting\%20format\%20Chlor\%20 alkali.doc 
Pauliuk S, Wang T, Müller D (2012) Moving towards the circular society, the role of stocks in the Chinese steel cycle. Environ Sci Technol 46:148-151

Pauliuk S, Wang T, Müller DB (2013) Steel all over the world: estimating in-use stocks of iron from 200 countries. Resour Conserv Recycl 71:22-30

Pauliuk S, Wood R, Hertwich EG (2015) Dynamic models of fixed capital stocks and their application in industrial ecology. J Ind Ecol 19:104-116

Peduzzi P (2014) Sand, rarer than one thinks. UNEP Global Environmental Alert Service (GEAS). http://www.unep.org/geas

Pohl WL (2011) Economic geology, principles and practice: metals, minerals, coal and hydrocarbons-an introduction to formation and sustainable exploitation of mineral deposits. Wiley-Blackwell, Hoboken

Radzevičius R, Velegrakis A, Bonne W, Kortekaas S, Gare E, Blažauskas N, Asariotis R (2010) Marine aggregate extraction regulation in EU member States. J Coastal Res 51:15-38

Ravishankar S (2015) Illegal beach sand mining of minerals in Tamil Nadu may be a scam worth Rs 1 lakh crore. Metals and mining. The economic times. http://articles.economictimes.indiatimes. com/2015-02-01/news/58675766_1_beach-sand-periyasamypuram-tuticorin-ashish-kumar

Robinson R, Brown M (2002) Sociocultural dimensions of supply and demand for natural aggregate-examples from the Mid-Atlantic region, USA, US Geological Survey open-file report 02-350

Senge P (1990) The fifth discipline. The art and practice of the learning organisation. Century Business, New York

Seppelt R, Manceur AM, Liu J, Fenichel EP, Klotz S Synchronized peak-rate years of global resources use, Ecol Soc 19:50-64. doi:10.5751/ES-07039-190450

Singer DA (1993) Basic concepts in three-part quantitative assessments of undiscovered mineral resources: nonrenewable resources, 2:69-81

Singer DA (1995) World class base and precious metal deposits-a quantitative analysis. Econ Geol 90:88-104

Singer DA (2007) Short course introduction to quantitative mineral resource assessments: US Geological Survey open-file report 2007-1434 [http://pubs.usgs.gov/of/2007/1434/]

Singer DA (2011) A lognormal distribution of metal resources. J China Univ Geosci 36:1-8

Singer DA (2013) The lognormal distribution of metal resources in mineral deposits. Ore geology reviews 55:80-86

Singer DA, Menzie WD (2010) Quantitative mineral resource assessments - an integrated approach. Oxford University Press, New York 219

Stanway D (2014) China steel output near peak, say executives, in bad news for miners. http://www.reuters.com/article/2014/03/06/ china-parliament-steel-idUSL3NOLT13W20140306

Steffen W, Broadgate W, Deutsch L, Gaffney O, Ludwig C (2015) The trajectories of the anthropocene: the great acceleration. the anthropocene review, 1-18. doi:10.1177/2053019614564785

Sterman JD (2000) Business dynamics, system thinking and modelling for a complex world. Irwin McGraw-Hill, New York

Stockwell LE (1999) World mineral statistics 1993-1997: production, exports, imports, Keyworth

Sutphin DM, Drew LJ, Fowler BK, Goldsmith R (2002) Techniques for assessing sand and gravel resources in glaciofluvial deposits-an example using the surficial geologic map of the Loudon quadrangle, Merrimack and Belknap counties, New Hampshire, with the surficial geologic map by Goldsmith R, Sutphin DM, US Geological Survey professional paper 1627

Sverdrup HU, Ragnarsdottir KV (2014) Natural resources in a planetary perspective: geochemical perspectives october issue. Eur Geochem Soc 2:1-156
Sverdrup H (2016) Modelling global extraction, supply, price and depletion of the extractable geological resources with the LITHIUM model. Res Conserv Recycl 114:112-129

Sverdrup H, Ragnarsdottir KV (2016) The future of platinum group metal supply; an integrated dynamic modelling for platinum group metal supply, reserves, stocks-in-use, market price and sustainability. Resour Conserv Recycl 114:130-152

Sverdrup H, Svensson M (2002) Defining sustainability. In: Sverdrup H, Stjernquist I (eds) Developing principles for sustainable forestry, results from a research program in southern Sweden, vol 5. Managing forest ecosystems Kluwer Academic Publishers, Amsterdam, pp 21-32

Sverdrup H, Svensson M (2004) Defining the concept of sustainability, a matter of systems analysis. In: M. Olsson, G. Sjöstedt (eds) Revealing complex structures-challenges for swedish systems analysis. Kluwer Academic Publishers, Alphen aan den Rijn, pp 122-142

Sverdrup H, Koca D, Granath C (2012a) Modeling the gold market, explaining the past and assessing the physical and economical sustainability of future scenarios. In: Schwanninger M, Husemann E, Lane D (eds) Proceedings of the 30th International Conference of the System Dynamics Society, St. Gallen, Switzerland, July 22-26, 2012. Model-based Management. University of St. Gallen, Switzerland; Systems Dynamics Society. Pages 5:4002-4023. ISBN: 9781622764143. Curran Associates, Inc

Sverdrup H, Koca D, Ragnarsdottir KV (2012b) The World 5 model; Peak metals, minerals, energy, wealth, food and population; urgent policy considerations for a sustainable society. In: Schwanninger M, Husemann E, Lane D (eds) Proceedings of the 30th International Conference of the System Dynamics Society, St. Gallen, Switzerland, July 22-26, 2012. Modelbased Management. pp 5:3975-4001. ISBN: 9781622764143 Curran Associates, Inc

Sverdrup H, Koca D, Ragnarsdottir KV (2013) Peak metals, minerals, energy, wealth, food and population; urgent policy considerations for a sustainable society. J Earth Sci Eng 2:499-534. ISSN 2159-581X

Sverdrup H, Koca D, Ragnarsdottir KV (2014a) Investigating the sustainability of the global silver supply, reserves, stocks in society and market price using different approaches. Resour Conserv Recycl 83:121-140

Sverdrup H, Ragnarsdottir KV, Koca D (2014b) On modelling the global copper mining rates, market supply, copper price and the end of copper reserves. Resour Conserv Recycl $87: 158-174$

Sverdrup H, Koca D, Ragnarsdottir KV (2015a) Aluminium for the future: modelling the global production, assessing long term supply to society and extraction of the global bauxite reserves. Resour Conserv Recycl 103:139-154

Sverdrup H, Koca D, Ragnarsdottir KV (2017a) Defining a free market: drivers of unsustainability as illustrated with an example of shrimp farming in the mangrove forest in South East Asia. J Cleaner Prod 140:299-311. doi:10.1016/j.jclepro.2015.06.087

Sverdrup HU, Ragnarsdottir KV, Koca D (2017b) An assessment of global metal supply sustainability: global recoverable reserves, mining rates, stocks-in-use, recycling rates, reserve sizes and time to production peak leading to subsequent metal scarcity. J Cleaner Prod 140:359-372. doi:10.1016/j.jclepro.2015.06.085

Sverdrup H, Ragnarsdottir KV, Koca D (2015b) Modelling the copper, zinc and lead mining rates and co-extraction of dependent metals, supply, price and extractable amounts using the BRONZE model. In: Proceedings of the 2015 word resources forum, 11-15 September. Davos, Switzerland

Sverdrup H, Ragnarsdottir KV, Koca D (2015c) Estimating critical extraction rates for the main metals for a sustainable society 
within the planetary limits. In: Proceedings of the 2015 word resources forum, September. Davos, Switzerland, pp 11-15

UNEP (2011) The UNEP yearbook 2011. UNEP division of early warning and assessment, Nairobi, Kenya

UNEP GEAS (2014) Sand, rarer than one thinks. Downloaded document.http://www.unep.org/pdf/UNEP_GEAS_March_2014. pdf

US department of the interior, Bureau of mines and Geological Survey (1980) Principles of a resource reserve classification for minerals, Geological Survey circular 831, Washington, DC

US Environmental Protection Agency (1994) Technical resource document extraction and beneficiation of ores and minerals. EPA 530-R-94-011

USGS (2009) US Geological Survey, 2009, Mineral commodity summaries 2009: Appendix C
USGS (2013) Sand and gravel (construction) statistics, In: Kelly TD, Matos GR (eds) Historical statistics for mineral and material commodities in the United States. US Geological Survey data series 140, Reston

USGS (2015) Commodity statistics for a number of metals (consulted several times 2008-2014). US Geological Survey. http://minerals.usgs.gov/ minerals/pubs/commodity/. 2005, 2007, 2008, 2013

van Oss H (2014) Cement. Mcs-2014-cemen.pdf. USGS website. US Geological Survey, mineral commodity summaries 38-39

Velegrakis AF, Ballay A, Poulos S, Radzevicius R, Bellec V, Manso F (2010) European marine aggregates resources: origins, usage, prospecting and dredging techniques. J Coastal Res 51:1-14. doi:10.2112/SI51-002.1 